\title{
Educational Mismatch And Returns On Human Capital In The Spanish Hospitality And Travel Agency Sectors
}

Alejandro García-Pozo, Ph.D. University of Malaga, Spain José Luis Sánchez-Ollero, Ph.D., University of Malaga, Spain Andrés Marchante-Mera, Ph.D., University of Malaga, Spain

\begin{abstract}
This paper investigates the importance of returns on human capital and educational mismatch in determining wages in the Spanish hospitality sector and the travel agency sector using an expanded version of the Mincer wage equation (1974). In addition, we analyze the impact of several job characteristics and personal characteristics on wages. Using data from the 2006 Spanish Wage Structure Survey, we estimate separate regressions for each education group under analysis: overeducated, undereducated and adequately educated workers, following the method used by Kiker et al. (1997) and using a procedure similar to that used by Strauss and Maisonneuve (2007). The regressions show specific estimated parameters of the variables included in all wage equations implemented for each analyzed group. Thus, educational mismatch is determinant for the returns on human capital in both sectors and it also has a significant and differential impact on wage formation in each educational group. Moreover, this fact has also been shown in the other variables of the model that represent both the personal characteristics of workers and job-specific characteristics. Therefore, according to the methodology used in our study, the real hourly wage may be quantitatively influenced by the variables in a model depending on whether the educational level of the workers matches the educational requirements of the job performed. Finally, it is important to note that evidence has been found regarding the impact of firm size on wage returns and the data also has provided evidence of wage differentials by gender in the Spanish hospitality industry.
\end{abstract}

Keywords: Wages; Gender; Firm-size; Educational Mismatch; Tourism

\section{INTRODUCTION}

(6) ne of the most remarkable changes in the Spanish economy in recent decades has been the significant increase in the educational level of Spanish workers. This has substantially changed supply in the Spanish labour market (Alba-Ramírez and Blázquez, 2003). Specifically, the estimations using data from the Spanish Economically Active Population Survey (EAPS) for 1996 to 2006 show a significant reduction in the number of active workers with no education at all $(-31.6 \%)$ or only primary school $(-27.4 \%)$, whereas the number of active workers with secondary school education (59.6\%), college/higher education vocational training (90\%), university education (87.9\%) or doctorates (199\%) has increased considerably. As pointed out by Marchante and Ortega (2010), this trend has also been observed in the Spanish hospitality sector. The weight of this sector in the Spanish GDP was $6.52 \%$ and represented $6.67 \%$ of total employment in the Spanish economy ${ }^{1}$ (year 2006). The relevance of this increase in the educational levels of Spanish workers and the importance of the hospitality sector in the Spanish economy does not exclude the possibility of mismatches between labour supply and demand in the labour market. In other words, for some occupational profiles, there is a mismatch or gap between the educational

\footnotetext{
${ }^{1}$ See http://www.ine.es/jaxi/menu.do?type=pcaxis\&path=\%2Ft35\%2Fp008\&file=inebase $\& \mathrm{~L}=0$ of the Spanish National Institute of Statistics, which publishes data from the Spanish National Accounts.
} 
levels of workers and the educational requirements demanded by firms to perform the tasks associated with the given job (Alba-Ramirez, 1993). As Salas Velasco (2001) points out, although in most sectors workers have an educational level that matches the requirements of the job, in other sectors the educational level of workers is higher (overeducated) or lower (undereducated) than that requested by the firms offering the job ${ }^{2}$.

The aim of this paper is to analyze the impact on wages of both the estimated returns from the different components of human capital as well as the variables that refer to specific characteristics of workers and jobs. The method used is an extended version of the wage function defined by Mincer (1974), based on the Ordinary Least Squares Estimation, and applied to each category of workers within the hotels and travel agency sectors in Spain. To this end, the worker categories mentioned above, based on the match between their educational level and the requirements of the job (adequately educated, overeducated and undereducated), are defined by placing the individual employees in each of the groups established. Therefore, the aim is to investigate whether the real hourly wage is influenced by the variables of the model in a quantitatively different way depending on the match or mismatch between the educational level of the worker and the requirements of the job. This article also compares and evaluates the results obtained from the separate estimates made for each education group. To the best of our knowledge, separate estimates of the gap between the educational level of the workers and the requirements of the job have not been performed for each of the education groups that workers are classified into. We used a sample from the Spanish Wage Structure Survey (2006) that includes professional, personal and job information on 15,964 workers in the hospitality sector and travel agencies in Spain.

This article is structured as follows: Section 2 described the methodology used in this work; Section 3 presents a brief descriptive analysis of the data and variables and includes the results of the estimates; and Section 4 presents the conclusions. Finally, we related the references used in this paper.

\section{METHODOLOGY}

The human capital theory is based on the neoclassical model of labour market performance and argues that educational mismatch is a temporary phenomenon that only occurs over the short term. The imbalance underlying this phenomenon is caused by the labour supply and demand mechanisms failing to function correctly. Human capital is one of the characteristics that define the job offer, and includes a large range of knowledge and skills that involves a stock of productive capital (Becker, 1964). Therefore, any activity that improves the quality (productivity) of the job should be considered an investment in human capital. This implies that education is not the only factor forming human capital; rather, work experience or tenure can also be considered an investment in human capital and workers will also obtain a return in terms of wages from these. Based on this theory, and consistent with Mincer's model (1974), the following wage equation includes these factors and is used in this study:

$\log (w r)=\beta_{0}+\beta_{1} S+\beta_{2}$ Exper $+\beta_{3}$ Exper $^{2}+\beta_{4}$ Tenure $+\beta_{5}$ Tenure ${ }^{2}+\beta_{6}$ Full-time $+\beta_{7}$ Permanent contract + $\beta_{8}$ Est.19+ $\beta_{9}$ Est.20-99 $+\beta_{10}$ Woman $+\varepsilon$

where the dependent variable $w r$ represents gross wage per hour worked. The explanatory variables include both human capital components and a set of specific variables regarding worker and job characteristics and, finally, $\varepsilon$ is a random disturbance term.

In our study, separate estimates of the wage function are performed for adequately educated, overeducated and undereducated workers after disaggregating our sample into these three education groups. This should provide estimates of the parameters of the explanatory variables in each of the wage functions that may differ from each other, thus demonstrating the different influence of the variables analyzed in this model on wages depending on the educational group workers belong to. However, before reaching this point, undereducation, overeducation and appropriate education in the context of job requirements must be defined. The statistical method used to measure the level of education required for the job is the one proposed by Kiker et al. (1997), which is based on the mode as the distribution measure, but also includes a corrective measure to avoid the drawbacks mentioned above. In this way, the database used allows us to calculate the most frequent level of education in each occupation (that is,

\footnotetext{
${ }^{2}$ For a more detailed explanation of these models, see Marchante et al. (2005). 
adequately educated workers) in a pooled sample of all workers in the hospitality and travel agency sectors in Spain. The mode is used as the statistical measure. Using a procedure similar to that used by Strauss and Maisonneuve (2007), the mode as a measure of educational mismatch is extended when the percentage of the mode is less than $40 \%$ of total employees in a given occupation as defined by the two-digit level of the Spanish National Classification of Occupations-CNO94 (INE, 1994).

As a consequence, workers with an educational level different from that required by their occupation are defined as follows: overeducated individuals are those who have attained an educational level higher than the one represented by the mode in each occupation (or greater than the highest education level used when two adjacent levels of education have considered); and undereducated individuals are those whose level of education is lower than the level of education represented by the mode of the occupation (or lower than the lowest education level used when two adjacent levels of education have considered). According to these definitions, our total sample is disaggregated into three groups of workers (adequately educated, overeducated and undereducated) in order to analyze each group separately regarding the effects of human capital and the characteristics of the workers and the job on wages.

\section{DATA AND RESULTS}

This study is based on the 2006 Spanish Wages Structure Survey (WSS-2006). This harmonized survey contains information provided by the management on the characteristics of their establishments and on individual employees and is representative of all establishments employing one or more workers. In this study, the activities included are hospitality industry -hotels and restaurants- and activities of travel agencies. In Table 1 we present the descriptive statistics of the variables used in this work.

The percentage distribution of educational groups are consistent with those obtained in other studies, both for the economy as whole in several European countries (Alba-Ramirez (1993), Hartog (2000), and Kiker et al. (1997), among others), and for the Spanish Hospitality sector (Marchante et al. (2004), Campos Soria et al. (2011), García Pozo et al. (2011) and García Pozo et al. (2012), among others). The gross hourly wage variable present unusual mean results obtained for each group analyzed: as shown in Table 1, the mean gross hourly wage of overeducated and undereducated workers is higher than for those with an educational level that matches the requirement of job they perform.

Table 1. Descriptive characteristics of the educational categories

\begin{tabular}{|c|c|c|c|c|c|c|c|c|}
\hline & \multirow{2}{*}{\multicolumn{2}{|c|}{ Total }} & \multirow{2}{*}{\multicolumn{2}{|c|}{ Adequately educated }} & \multirow{2}{*}{\multicolumn{2}{|c|}{ Over-educated }} & \multirow{2}{*}{\multicolumn{2}{|c|}{ Under-educated }} \\
\hline & & & & & & & & \\
\hline & Mean & St. Dev. & Mean & St. Dev. & Mean & St. Dev. & Mean & St. Dev. \\
\hline Hourly gross wage (€) & 10.09 & $(7.72)$ & 9.37 & (4.92) & 11.48 & $(13.26)$ & 10.77 & $(6.62)$ \\
\hline Education (years) & 8.27 & (3.92) & 7.81 & $(3.01)$ & 12.75 & $(2.54)$ & 5.39 & (3.62) \\
\hline Experience (years) & 15.30 & $(10.35)$ & 16.13 & $(10.40)$ & 10.94 & $(9.11)$ & 17.09 & (10.18) \\
\hline Tenure (years) & 5.97 & $(8.24)$ & 5.61 & $(7.86)$ & 5.68 & (7.99) & 7.18 & $(9.27)$ \\
\hline Full-time contract & 0.73 & $(0.44)$ & 0.72 & $(0.45)$ & 0.72 & $(0.45)$ & 0.76 & $(0.43)$ \\
\hline Permanent contract & 0.76 & $(0.43)$ & 0.75 & $(0.43)$ & 0.76 & $(0.43)$ & 0.78 & $(0.42)$ \\
\hline Est. 19 & 0.22 & $(0.41)$ & 0.23 & $(0.42)$ & 0.17 & $(0.38)$ & 0.22 & $(0.41)$ \\
\hline Est. 20-99 & 0.35 & $(0.48)$ & 0.35 & $(0.48)$ & 0.36 & $(0.48)$ & 0.36 & $(0.48)$ \\
\hline Woman & 0.55 & $(0.50)$ & 0.57 & $(0.50)$ & 0.49 & $(0.50)$ & 0.55 & $(0.50)$ \\
\hline Obs. & \multicolumn{2}{|c|}{$15964(100 \%)$} & \multicolumn{2}{|c|}{$9292(58.21 \%)$} & \multicolumn{2}{|c|}{$3195(20.01 \%)$} & \multicolumn{2}{|c|}{$3477(21.78 \%)$} \\
\hline
\end{tabular}

Source: WSS-2006 and own data.

Table 2 shows the results of the estimates obtained with equation (1). The estimates of the coefficients of the human capital variables in the full sample show that, providing everything else remains constant ${ }^{3,4}$, returns to

\footnotetext{
${ }^{3}$ This condition is applicable to the remaining comments in this section.

${ }^{4}$ The impact on wages of the dummy variables when using a semilog function was calculated by taking the antilogarithm of the corresponding coefficient, subtracting 1 and multiplying by 100 (Halvorsen and Palmquist, 1980).
} 
education in this sector is $2.72 \%$, whereas returns to previous experience and tenure ${ }^{5}$ are $0.31 \%$ and $2.27 \%$, respectively. Compared to earlier studies (Pastor et al. (2006), Lillo-Bañuls and Casado-Diaz (2010), and Garcia Pozo et al. (2012), among others), these results are similar when one take into account that our specification includes additional variables for the characteristics of the jobs. Introducing these additional variables has the effect of reducing the value of the estimated coefficient for the variable years of schooling because these variables capture part of the indirect effect of education on wages and productivity. Consequently, the returns to education estimated in this paper show the direct effect of education, once the effects of the job characteristics are removed.

Regarding the dummy variables for the job characteristics, the positive wage premium provided by fulltime contracts $(7.77 \%)$ and permanent contracts $(7.52 \%)$ in this sector is striking when compared to other more precarious types of contracts. In addition, the two variables that measure the impact of firm size on wages in relation to the reference variable (firms with 100 employees or more) indicate that the smaller the establishment the greater the wage penalty for the hospitality and travel agency workers, reaching $13.47 \%$ in small businesses compared to large ones. Regarding the personal characteristics of workers, it should be noted that the impact of gender on wages is very important in this sector, as there is a $13.38 \%$ wage penalty due to being female as compared to male workers.

Table 2. Earnings function estimates (dependent variable: Log of hourly gross wage)

\begin{tabular}{|c|c|c|c|c|c|c|c|c|}
\hline & \multicolumn{2}{|c|}{ Total } & \multicolumn{2}{|c|}{ Adequately educated } & \multicolumn{2}{|c|}{ Over-educated } & \multicolumn{2}{|c|}{ Under-Educated } \\
\hline Education & $0.0272 *$ & $(0.0009)$ & $0.0366 *$ & $(0.0015)$ & $0.0311 *$ & $(0.0030)$ & $0.0476 *$ & $(0.0020)$ \\
\hline Experience & $0.0075^{*}$ & $(0.0010)$ & $0.0043 *$ & $(0.0013)$ & $0.0127 *$ & $(0.0025)$ & $0.0118^{*}$ & $(0.0024)$ \\
\hline Experience sq. & $-0.0001 *$ & $(0.0000)$ & $-0.0001 *$ & $(0.0000)$ & $-0.0003 *$ & $(0.0001)$ & $-0.0002 *$ & $(0.0001)$ \\
\hline Tenure & $0.0254 *$ & $(0.0012)$ & $0.0207 *$ & $(0.0015)$ & $0.0335 *$ & $(0.0034)$ & $0.0262 *$ & $(0.0024)$ \\
\hline Tenure sq. & $-0.0002 *$ & $(0.0000)$ & $-0.0001 *$ & $(0.0000)$ & $-0.0005^{*}$ & $(0.0001)$ & $-0.0002 *$ & $(0.0001)$ \\
\hline Full-time contract & $0.0749 *$ & $(0.0068)$ & $0.0311 *$ & $(0.0083)$ & $0.1243 *$ & $(0.0166)$ & $0.0898 *$ & $(0.0157)$ \\
\hline Permanent contract & $0.0725 *$ & $(0.0070)$ & $0.0555 *$ & $(0.0085)$ & $0.0796 *$ & $(0.0171)$ & $0.0998 *$ & $(0.0157)$ \\
\hline Est. 19 & $-0.1447 *$ & $(0.0069)$ & $-0.1381 *$ & $(0.0081)$ & $-0.1825^{*}$ & $(0.0174)$ & $-0.1080 *$ & $(0.0156)$ \\
\hline Est. 20-99 & $-0.0726^{*}$ & $(0.0064)$ & $-0.0570 *$ & $(0.0077)$ & $-0.0948^{*}$ & $(0.0157)$ & $-0.0752 *$ & $(0.0133)$ \\
\hline Woman & $-0.1437 *$ & $(0.0057)$ & $-0.1303^{*}$ & $(0.0068)$ & $-0.1609 *$ & $(0.0149)$ & $-0.1844 *$ & $(0.0120)$ \\
\hline Constant & $1.8071 *$ & $(0.0151)$ & $1.7859 *$ & $(0.0199)$ & 1.6534* & $(0.0473)$ & $1.7090 *$ & $(0.0339)$ \\
\hline Observations & 15964 & & 9292 & & 3195 & & 3477 & \\
\hline $\mathbf{R}^{2}$ ajusted & 0.3360 & & 0.3242 & & 0.3169 & & \begin{tabular}{|l|}
0.4574 \\
\end{tabular} & \\
\hline F-test & $535.42 *$ & & 297.91* & & $100.97 *$ & & $230.97 *$ & \\
\hline RSS & 18.810 .026 & & 8.909 .788 & & 4.925 .238 & & 4.029 .679 & \\
\hline
\end{tabular}

Note: Significant at: $* 1 \%$ and $* * 5 \%$. White-corrected standard errors are in parentheses.

Source: WSS-2006.

The data presented in Table 2 show significant differences between each educational group, as well as the differential impact of each variable analyzed, especially those referring to human capital, on the wages of each group. Regarding human capital variables, it must be emphasized that the returns to education in the hospitality sector are low, regardless of the education group under consideration, which confirms the results of Pastor et al. (2006), Marchante et al. (2005) and García Pozo et al. (2011), among others). However, there are significant differences between the groups analyzed. As in the previous case, the impact on wages for adequately educated workers $(1.91 \%)$ is less compared to other workers. Overeducated workers compensate for lower returns to education by returns to other components of human capital, when compared to the results obtained for adequately educated workers. On the other hand, undereducated workers earn significant returns to their lower educational level compared to other groups of workers, a fact which may be conditioned by the special characteristics of this sector in Spain, as indicated by Garcia Pozo et al. (2011).

The differential impact on wages of the personal and job characteristics variables, according to the estimates, between adequately educated, overeducated and undereducated workers is very significant. Regarding the variables that refer to types of contracts, the wage premium earned by workers with educational mismatch is much higher than that of adequately educated workers, with more than 10 percentual points difference in the case of full-

\footnotetext{
5 The estimated return to experience and tenure is derived as follows: $\left(\beta_{2}+2 \beta_{3}\right.$ Experience $)$ and $\left(\beta_{4}+2 \beta_{5}\right.$ Tenure $)$, where Experience and Tenure are the average level of these variables for each group of workers. 
time contracts versus temporary contracts between overeducated and adequately educated workers. Secondly, the size of the firm also has a different impact on the education groups analysed. In companies with 100 employees or more, adequately educated workers suffer the least penalty on wages due to working in such an establishment $(5.55 \%)$, whereas the greatest negative impact on wages is among overeducated workers working in small firms $(16.68 \%)$. These data may be explained by the low qualifications that most small businesses in this sector (in many cases, restaurants) demand from workers. Third, the wage gap due to gender significantly affects all female workers, regardless of the educational match for their job. The wage penalty for women versus men reaches its maximum difference among adequately educated $(12.21 \%)$ and undereducated workers $(16.84 \%)$, the difference being around $37.91 \%$. This wage penalty may be due to the type of jobs performed by women in the hospitality sector, because these often require less education than those performed by men, as noted by García Pozo et al. (2011).

\section{CONCLUSIONS}

Using data from the Spanish hospitality industry and travel agencies, we have confirmed that the human capital variables of workers have a differential impact on wages, depending on the match between the educational level of employees and that required by their jobs. The educational categories - adequately educated, overeducated and undereducated workers - were defined using the mode as the statistical measure, although this was expanded in cases where the mode was less than $40 \%$ of the total employees in each occupation, as defined by the two-digit level of the National Classification of Occupations-CNO94. This approach was used to reduce measurement errors. Once the sample was disaggregated into these three categories, in contrast to the studies that use dummy variables to analyze this phenomenon, we estimated the same wage function for each category.

The results confirmed that returns to human capital (educational level, previous experience and tenure in the job) of workers in the Spanish hospitality sector and travel agencies are statistically different when adequately educated, overeducated and undereducated workers are considered separately. In addition, the values obtained in the estimates are consistent with those reported in earlier work on this sector in the Spanish economy.

Furthermore, and in line with the economic literature on educational mismatch, it was confirmed that the returns to education in the Spanish hospitality for overeducated workers are positive but lower than those obtained by adequately educated workers, who also have positive returns, although these are lower than those obtained by undereducated workers. The three values are also statistically different from each other. On the other hand, the estimates for each educational category are also significantly different regarding previous experience and tenure in the job. This has also been demonstrated for the variables in the model that represent the personal characteristics of workers and the job-specific characteristics. Therefore, according to the methodology used in our study, the real hourly wage may be quantitatively influenced by the variables in this model depending on whether the educational level of the workers matches the educational requirements of the job performed or not.

It is important to note that evidence has been found regarding the impact of firm size on wage returns, and that the returns are lower, the smaller the size of the firm. This has a particular impact on the wages of overeducated workers working in small firms whose salary is significantly lower.

Finally, the analysis of the data has provided evidence of wage differentials by gender in the Spanish hospitality industry. This gap can be explained by the nature of the work predominantly carried out by this segment of workers.

\section{AUTHOR INFORMATION}

Alejandro García-Pozo, Ph.D. and Degree in Economics \& Business Studies by University of Malaga. Senior Lecturer in Economics at University of Malaga. Faculty of Economics \& Business Studies. Department of Applied Economics. University of Malaga (Spain). Research Interest: Labor market, productivity and wages, returns on human capital and sustainable development in tourism sector. E-mail: alegarcia@uma.es 
José Luis Sánchez-Ollero, Ph.D. and Degree in Economics \& Business Studies by University of Malaga. Senior Lecturer in Economics at University of Malaga. Faculty of Economics \& Business Studies. Department of Applied Economics. University of Malaga (Spain). Research Interest: Labor market, productivity and wages, returns on human capital and sustainable development in tourism sector. E-mail: jlsanchez@uma.es (Corresponding author)

Andrés Marchante-Mera, Ph.D. and Degree in Economics \& Business Studies by University of Malaga. Professor in Economics at University of Malaga. Faculty of Economics \& Business Studies. Department of Applied Economics. University of Malaga (Spain). Research Interest: Productivity analysis and labor supply. E-mail: marchante@uma.es

\section{REFERENCES}

1. Alba-Ramírez, A. (1993): “Mismatch in the Spanish Labor Market. Overeducation?”, Journal of Human Resources, Vol. 28, No. 2, pp. 259-278.

2. Alba-Ramírez, A. and Blázquez, M. (2003): “Types of job match, overeducation and labour mobility”, in F. Büchel,

3. Becker, G.S. (1964): Human Capital: A Theoretical and Empirical Analysis, with Special Reference to Education. University of Chicago Press, Chicago.

4. Campos Soria, J.A., García Pozo, A., Sánchez Ollero, J.L. and Benavides Chicón, C. (2011): "A comparative analysis on human capital and wage structure in the Spanish hospitality sector", Journal of Service Science and Management, Vol. 4, No. 4, pp. 458-468.

5. García-Pozo, A., Marchante-Mera, A. and Sánchez-Ollero, J.L. (2011): “An analysis of occupational differences in the return on human capital in Spanish travel agency and hospitality industries", Tourism Economics, Vol. 17, No. 6, pp. 1325-1345.

6. García-Pozo, A., Campos-Soria, J.A.,Sánchez-Ollero, J.L. and Marchante-Lara, M.(2012): "The regional wage gap in the Spanish hospitality sector based on a gender perspective", International Journal of Hospitality Management, Vol. 31, No. 1, pp. 266-275.

7. Halvorsen, R. and Palmquist, R. (1980): "The interpretation of dummy variables in semilogarithmic equations". American Economic Review, Vol. 70, No. 3, pp. 474-475.

8. Hartog, J. (2000): "Human capital as an instrument of analysis for the economics of education", European Journal of Education, Vol. 35, No. 1, pp. 7-20.

9. Instituto Nacional de Estadística (INE) (1994): Clasificación Nacional de Ocupaciones, INE, Madrid.

10. Kiker, B.F., Santos, M.C. and Mendes de Oliveira, M. (1997): "Overeducation and undereducation: Evidence for Portugal", Economics of Education Review, Vol. 16, No. 2, pp. 111-125.

11. Leuven, E. and Oosterbeek, H. (2011): "Overeducation and mismacht in the labor market", in Hanushek, E.,

12. Lillo-Bañuls, A. and Casado-Díaz, J.M. (2010): "Rewards to education in the tourism sector: one step ahead", Tourism Economics, Vol. 16, No. 1, pp. 11-23.

13. Marchante, A.J. and Ortega, B. (2010): "Capital humano, desajuste educativo y productividad del trabajo: un estudio para la industria hotelera", Cuadernos de Economía y Dirección de la Empresa, No. 44, pp. 79100 .

14. Marchante, A.J., Ortega, B. and Pagán, R. (2005): "Educational mismatch and wages in the hospitality sector", Tourism Economics, Vol. 11, No. 1, pp. 103-117.

15. Marchante, A.J., Ortega, B. and Sánchez Ollero, J.L. (2004): "Desajuste educativo y movilidad laboral de los trabajadores de la hostelería en Andalucía", Revista de Estudios Regionales, No. 69, pp. 57-88.

16. Mincer, J. (1974): Schooling, Experience, and Earnings, Columbia University Press, New York.

17. Pastor, J.M., Raymond, J.L., Roig, J.L. and Serrano, L. (2006): El Rendimiento del Capital Humano en España, IVIE, Valencia, Spain.

18. Salas Velasco, M. (2001): Aspectos Económicos de la Educación, Grupo Editorial Universitario, Granada, Spain.

19. Strauss, H. and Maisonneuve, C. (2007): "The wage premium on tertiary education: New estimates for 21 OECD countries", OECD Economics Department Working Papers, No 589, OECD Publishing. 